\title{
Formulating and Validating Sustainable Residential Area Indicators in Suburban Metropolitan Jakarta
}

\author{
Pitri Yandri ${ }^{1 *}$ Dominicus Savio Priyarsono ${ }^{2}$ Akhmad Fauzi ${ }^{3}$ Arya Hadi \\ Dharmawan $^{4}$ \\ 1 Ahmad Dahlan Institute of Technology \& Bisnis \\ 2 Department of Economics, IPB University \\ 3 Rural and Regional Development Planning Sciences Study Program, IPB University \\ 4 Department of Human Ecology, IPB University \\ *Corresponding Author,Email:p.yandri@gmail.com
}

Received: March 21, 2020 Accepted: May 11, 2021

Key words: Residential area, Infrastructure, Governance, Technology, Sustainability

\begin{abstract}
In today's empirical studies on sustainability, researchers still rely on the concept of "triple bottom lines" (economic, social, and environmental), which are influential in covering development issues. However, this concept has limitations for specific cases, such as regional, local, and sectoral levels. One sector that should adopt sustainability principles is the residential area in the suburban area. The academic discourse on sustainable residential area (SRA) is still requiring extensive research, especially on generating reliable and valid indicators. In the policy arena, particularly in Indonesia, an accurate indicator of measuring SRA is not available. Thus, this study intends to develop and validate the SRA indicators. The "citizen-led" approach was used in this study to observe 332 households spread in the cities of South Tangerang, Tangerang, Depok, and Bekasi. These cities are spatially located in the hinterland of Greater Jakarta. Households are divided into residential and non-residential area households. By extending into a literature review, this study develops 51 SRA indicators grouped into economic, social, environmental, infrastructure, technology, and governance parameters. Moreover, using structural equation modelling with a confirmatory factor analysis approach, this study generates 36 valid and reliable SRA indicators. This study provides that the model could be considered a structure and system that enhances the SRA.
\end{abstract}

\section{INTRODUCTION}

In many economic development textbooks, the concept of sustainable development still refers to the definition of the World Commission on Environment and Development (WCED). It defines sustainability as the "patterns of development that meet the needs of the present generation without jeopardizing the ability of future generations to meet their own needs" (WCED, 1987). After ten years, Elkington (1997) introduced the concept of "triple bottom lines" (social, economic, and environmental) as the basic concepts of interrelation in interpreting the concept of sustainability. Although the concept is used as a primary reference in empirical research, it has not been considered yet, and debate among academics, particularly for the local context and specific cases, continues (Seghezzo, 2009). Therefore, 
the opportunity to bridge the gaps is still wide open. Moreover, much research shows that sustainability has shifted from a global perspective to a meso perspective: local, regional, and sectoral (Finco and Nijkamp, 2001).

For example, in the context of urban sustainability, Talen (2014) states that the issues at this level revolve around housing, transportation, the environment, and the interconnection of administrative governance. Especially for housing, the academic discourse on sustainable housing areas has prompted the attention of researchers and the government. For instance, Yigitcanlar et al. (2015) conducted empirical research on sustainable housing in Malaysia. Meanwhile, Pakzad and Salari (2018) examined sustainable housing in Iran by observing a small-size neighbourhood. In Indonesia, Sudarwanto et al. (2014) conducted a study on the formulation of indicators of sustainable housing areas. In the policy arena, such as in Germany, a certification system is implemented to assess whether a housing area is sustainable or not (Rid et al., 2017).

A brief description of some empirical studies and their implementation for the policymaker raises a fundamental question of why housing areas must comply with sustainable principles. Winston and Eastaway (2008) provide four arguments. First, housing is a critical public policy domain that can affect urban development and potentially contribute to sustainable development. Second, housing construction, including its design, has a significant impact on the environment. Third, housing construction and its facilities affect how we manage waste. Fourth, housing development impacts the use of electricity, wood, and so on, and it directly affects sustainability.

In Indonesia, the idea of implementing a sustainable housing area has not received serious attention. Although the National Development Planning Agency of the Republic of Indonesia has issued regulation No. 7/2018 concerning Coordination, Planning, Monitoring, Evaluation, and Reporting on the Implementation of Sustainable Development Goals, the regulation focuses on how residents obtain accessibility to basic needs for decent and affordable housing. In other words, the regulation has not paid attention to how a housing area meets the principles of sustainability. Achievement of sustainable housing areas is relevant when it is related to the reality and phenomena faced in known suburban areas today, such as South Tangerang, Tangerang, Depok, and Bekasi.

Their spatial characteristics face various spill-over effects, such as economic, social, spatial, and environmental impacts. One example of spillover effects is the continuing increase in population due to migration from rural to urban areas and migration from the city centre to the suburbs. The Regional Statistics Agency shows that the population is continuously increasing. In the last eight years (2010-2018), the average population growth rate increased by $2.16 \%$ in Tangerang City, $3.56 \%$ in South Tangerang City, 3.53\% in Depok City, and $2.50 \%$ in Bekasi City.

In turn, increased population growth will reduce the demand for land, especially for housing and settlements. Housing developers then followed up the process to build a residential area to respond to the increased demand. Empirical evidence shows that residential land area increased from $60.07 \%$ in 2011 to $61.79 \%$ in 2016 , equivalent to a $1.72 \%$ increase or $2.53 \mathrm{~km} 2$ of the total area of $147.19 \mathrm{~km} 2$. In Depok City, in 2005, the residential land area reached $44.31 \%$ of the total land area, which increased to $53.24 \%$ in 2012. Meanwhile, in Bekasi City during 2005-2014, land changes for settlements reached 250.32 ha or $58.48 \%$. Although residential land in Tangerang City in 2010 was only $22.13 \%$ of the total area, the number 
increased to $26.54 \%$ in 2013 . The growth of the residential land area in Tangerang City reaches an average of $6 \%$ per year.

In addition to these facts and phenomena, Indonesia does not have official indicators to measure the sustainability of housing areas. Although the Minister for Public Works and Human Settlements tried designing sustainable urban settlements in 2014, the concept has not yet been manifested as a concrete public policy. Alternatively, the National Standardization Agency (BSN) of the Republic of Indonesia also released the Procedures for Urban Environmental Planning in the City with Indonesian National Standard (SNI) 03-1733-2004 (BSN, 2004). The SNI is indeed oriented toward sustainability, but several indicators still have not adapted other dimensions of sustainability, such as social and economic. Based on this description, this study aims (1) to develop variables and indicators of sustainable housing areas (from now on referred to as sustainable residential area/SRA) in suburban areas and (2) to validate the constructs and indicators that have been devised.

\section{LITERATURE REVIEW}

In scientific articles, the terms pointing to settlements and housing, for example "housing", "settlements", "residential area", and "neighbourhood", vary greatly. In the Oxford English Dictionary, "housing, or more generally living spaces, refers to the construction and assigned usage of houses or buildings collectively, for sheltering people - the planning or provision delivered by an authority - with related meanings." Meanwhile, "settlement" is defined as "a place where people live together".

Furthermore, the "residential area" used in which housing predominates, as opposed to industrial and commercial areas, includes single-family housing, multi-family residential, or mobile homes. In some literature, a residential area is also called a housing cluster (Hapsariniaty et al., 2013) or a housing complex (Kerr, 2008). In 2002, Leisch referred to the residential area as a gated community.

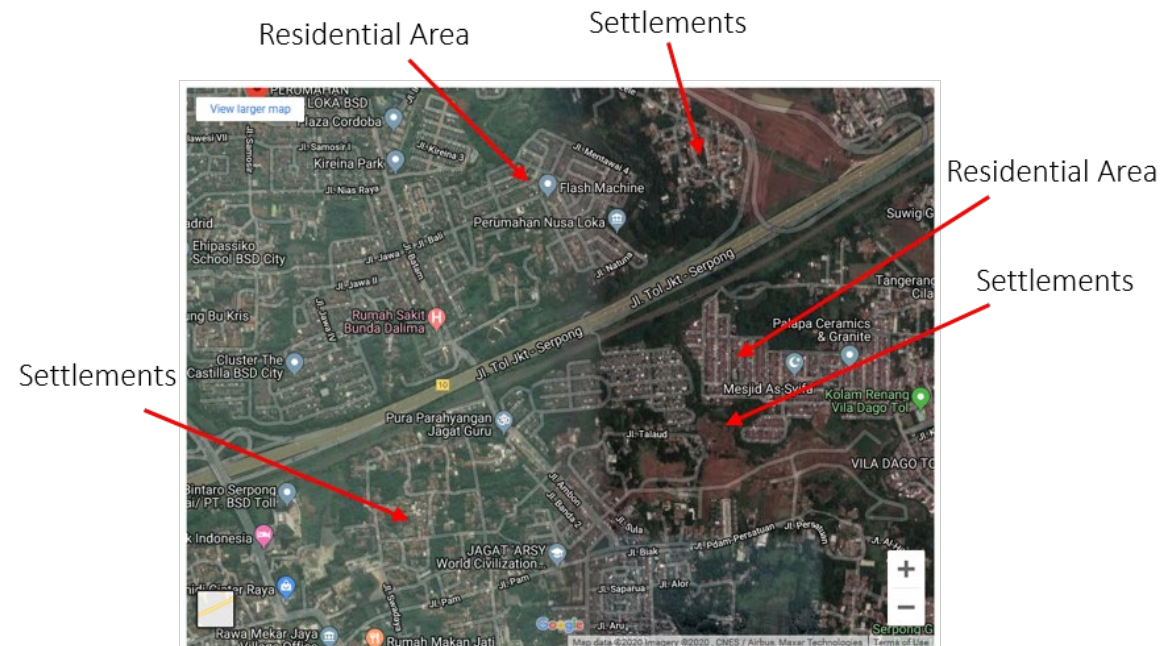

Figure 1. Distinction between residential area and settlement in Suburban Metropolitan Jakarta, Indonesia

In legal-formal terms in Indonesia, housing is part of the settlement. The characteristic differentiator between settlements and housing is that apart 
from having the boundaries of ownership and authority, settlements are built by communities individually. In contrast, housing is built by the private or government sector. Thus, the knot line that the housing is a residential area can be quickly drawn. In Indonesia, a residential area built in the private sector is sold back to the community. An example of a residential building by the private sector is BSD City, a large housing company in Indonesia. Another example of housing built by the government, is that such as police housing or state university lecturers housing. From the perspective of their spread pattern, the housing is more organized than the settlement. Figure 1 shows actual illustrations in spatial maps of housing and settlements.

From the perspective of regional economics, the emergence of residential areas positively impacts generating additional resources in human capital. It has a function as an engine of growth (World Bank, 2009). This viewpoint resonates with Robert Lucas (1967-1981) through his economic growth theory (Andrada, 2017). For Lucas, the process will eventually approach convergent economic growth. Moreover, because of Lucas, labour mobility and capital would help economic concentration, and this flow mitigates differences in well-being that can accompany the economic concentration. In the policy arena, this perspective will result in facilitation and making efforts, especially by middle-class residents who have the skills and education (World Bank, 2009).

However, several studies related to residential areas inform us that residential areas changed the livelihood strategy of people working in the agriculture sector (Elhadary et al., 2013; Liu and Liu, 2016) because construction transforms agricultural land. Besides this, residential areas suppress social capital (Clark, 2007), put pressure on minority community groups (Ragusett, 2014), and cause the emergence of economic inequality and revenues (Huang and Jiang, 2009; Neckerman et al., 2009; Yandri, 2014; Zhao, 2016), social segregation (Yandri, 2015), and settlement segregation (Hwang, 2015). The emergence of residential areas precisely resulted in the low political participation of its citizens (Schram, 1991). The study of the situation was verified by Newman et al. (2013) in the United States and (Yandri, 2017) in South Tangerang Municipality, Indonesia. All such information implies that residential areas should apply sustainability principles.

As stated in the introduction section, the study of sustainability has covered the specific arena of development with a varied context. In a spatial context, many studies focus on rural and urban sustainability. In rural areas, the focus is on household livelihood issues, as mentioned in Deng et al. (2020), or the sustainability of spatial interactions between the two regions (Ji et al., 2019). For example, Buchori and Sugiri (2016) use the terminology "sustainable metropolitan" to encourage applicable policies while maintaining the concept of triple bottom lines. The progress made by various studies related to sustainability is attractive regarding the idea, methodology, and approach. Unfortunately, the study still places three fundamental pillars as the basis for analysis and development. Therefore, our study implemented a new concept by adding two advanced pillars to complement the previous three pillars (Figure 2). 


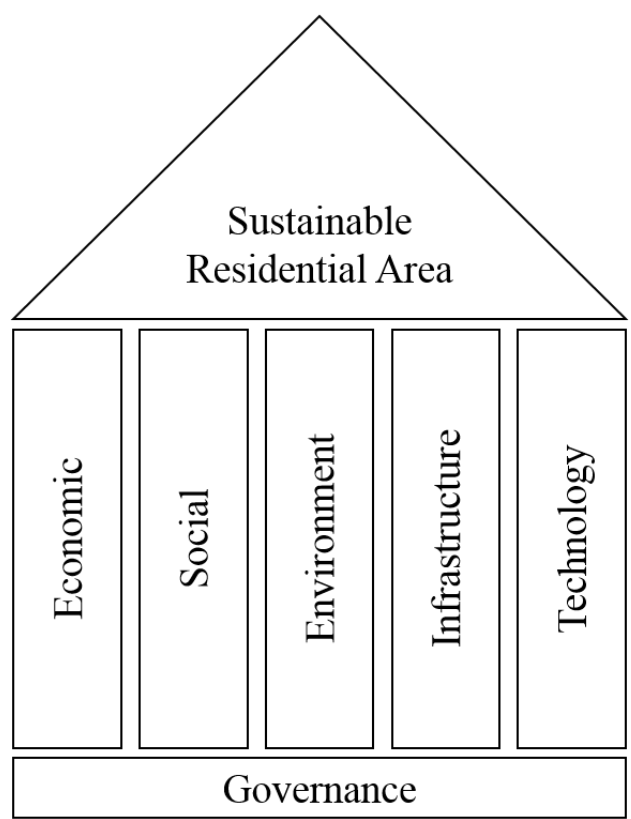

Figure 2. The theoretical framework of sustainable residential area

The formulation of the pillar is undoubtedly opposed by the mainstream, which generally understands the academic discourse on sustainability. In classic sustainability, its pillar comprises economic, social, and environmental (triple bottom lines), as mentioned by Elkington (1997). However, this article examines new parameters, especially in residential areas, namely infrastructure, technology, and governance as the foundation (Figure 2). The consideration to include infrastructure parameters relies on the argument that the situation of the residential area in urban/suburban areas is undoubtedly different compared with that in rural areas. The social, economic, and spatial conditions in urban/suburban are characterised by the middle-class population (Ningrum et al., 2014), which has a higher demand for sophisticated and accessible infrastructure facilities than people in rural areas.

Related to the technology parameter, (Bugliarello, 2004) states the critical role of technology in achieving sustainable development. A focus on urban sustainability must involve the necessity of technology in answering the question "what can we do?". Technology is needed to translate our understandings into designs and functions that enhance urban and global sustainability. Cities with complex structures from the social and economic aspects require an integrated response to overcome their problems and challenges. Technology enables urban governance to be more participatory and contributes to social inclusion by increasing the availability of facilities for planners to respond to service needs. Therefore, the application of technology contributes to urban sustainability (United Nations, 2015).

Why does governance need to be the foundation? Citing Jha and Murthy (2000), we found that the current concept of sustainability is incomplete because it excludes the spatial aspects and behaviour and property rights in the model. They stated that human behaviour changes and endogenously confirmed property rights would eventually change sustainability. Therefore, one of their five important proposals is nonmarket intervention, implying that government elements have become a new sustainability issue through governance. Governments are considered because they involve the question of "do their policies contribute to the achievement of sustainable development?" (Evans et al., 2006) 


\section{STUDY AREA}

We observed Tangerang, South Tangerang, Depok, and Bekasi (Figure 3 ), small towns with autonomy and self-government. In these cities, massive residential areas are large, medium, and small in various land sizes. In South Tangerang, for example, BSD City and Bintaro Jaya developers are under the management of Sinar Mas Land and Jaya Property Corporation, respectively. In Bekasi and Tangerang, Sumarecon Agung Corporation developed Sumarecon Residential Area. These residential development companies are the largest in Indonesia.

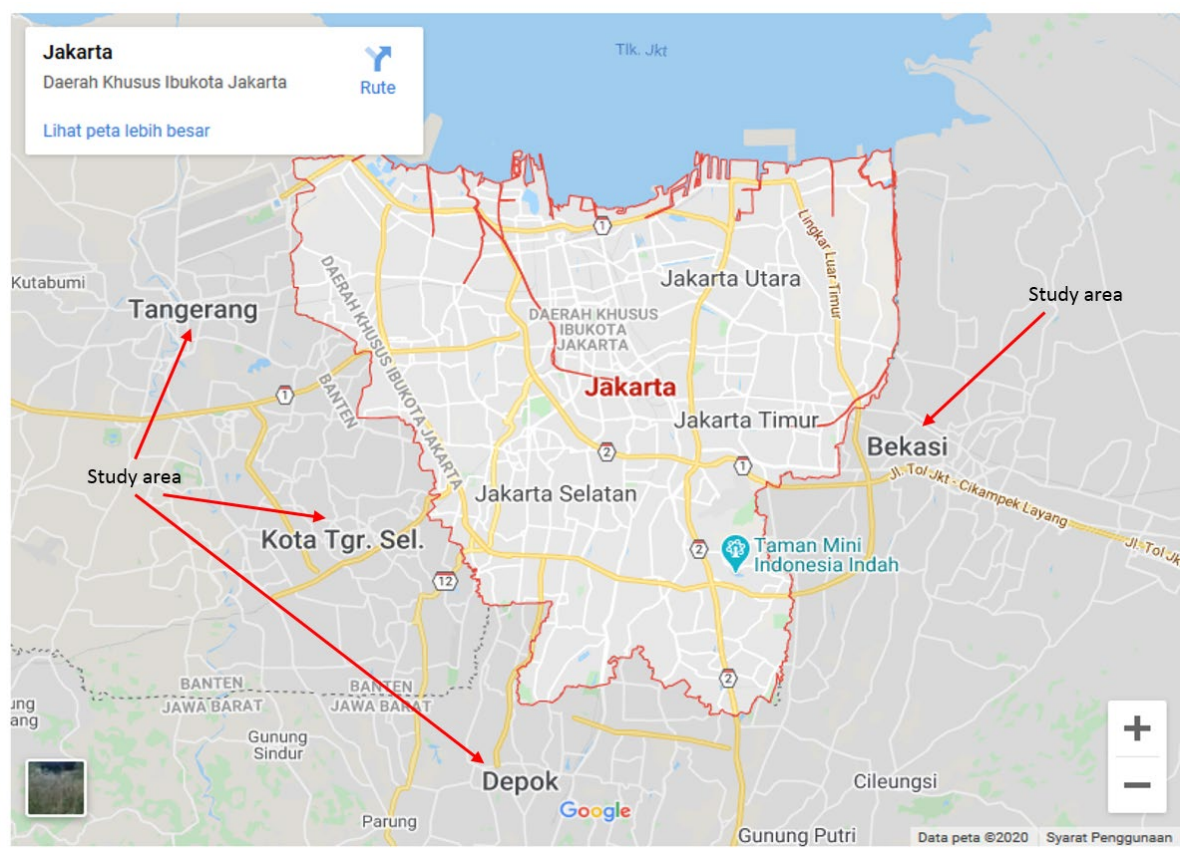

Figure 3. Suburban Metropolitan Jakarta, Indonesia

The private sector's contribution to the construction of large residential areas impacts the economies of those cities. For instance, South Tangerang is an area dominated by tertiary sectors: trade, hotels, restaurants, transport and communication, banking and financial institutions, and services and real estate (Table 1).

Table 1. GDRP by industry in South Tangerang, Tangerang, Bekasi, and Depok City (\%)

\begin{tabular}{lrrrr}
\hline GDRP by industry & \multicolumn{1}{l}{$\begin{array}{l}\text { South } \\
\text { Tangerang }\end{array}$} & Tangerang & Bekasi & Depok \\
\hline Agriculture, forestry, and fishing & 0.25 & 6.96 & 0.96 & 1.40 \\
Mining and quarrying & 0.00 & 0.00 & 0.00 & 0.00 \\
Manufacturing & 9.64 & 3.72 & 34.34 & 31.13 \\
Electricity and gas & 0.14 & 6.80 & 1.94 & 0.31 \\
Water supply, sewerage, waste management, & 0.04 & 8.04 & 0.09 & 0.07 \\
and remediation activities & & & & \\
Construction & 15.81 & 6.70 & 11.00 & 19.31 \\
Wholesale and retail trade; repair of motor & 16.80 & 4.94 & 22.60 & 21.75 \\
vehicles and motorcycles & & & & \\
Transportation and storage & 3.32 & 8.67 & 10.18 & 4.54 \\
Accommodation and food service activities & 3.12 & 8.90 & 3.88 & 3.75 \\
Information and communication & 11.03 & 9.24 & 2.06 & 1.86 \\
Financial and insurance activities & 1.28 & 2.91 & 3.09 & 4.05 \\
Real estate activities & 17.32 & 8.11 & 1.57 & 1.57 \\
Business activities & 3.83 & 7.17 & 0.45 & 0.20 \\
Public administration and defence, compulsory & 1.35 & 5.18 & 1.98 & 2.63
\end{tabular}


social security

Education

Human health and social work activities

8.77

$\begin{array}{lll}7.46 & 2.30 & 2.73\end{array}$

Other services/ activities

$\begin{array}{llll}4.16 & 8.04 & 1.08 & 1.08\end{array}$

Source: Local Statistical Bureau, 2019

\section{METHOD}

Several studies related to efforts to develop sustainability indicators were adopted based on regional (local) values through a combination of expert-led and citizen-led approaches (Turcu, 2013), based either on literature studies such as those conducted by Aulia (2016) and Xu et al. (2018), or based on secondary data such as the study of Shiau et al. (2015). Then they used the rough sets theory method and two-stage principal component analysis. Following Turcu (2013), Aulia (2016), and Xu et al. (2018), we use the SRA indicator formulation in this study from the literature. We use (Olsson et al., 2004) framework in determining the relevance indicator, which are: (1) relevant to decision-making, (2) clear in value, (3) adequate in scope, (4) feasible, parsimonious, and adequately communicated, (5) democratic/participatory, (6) integrated/ multidimensional, and distributional, (7) forward-looking, physical, and comparable. Furthermore, the selected indicator should meet suburban characteristics in Indonesia. Starting now, we validate it with a citizen-led approach by household perceptions. The observed households live in residential and non-residential areas in Suburban Metropolitan Jakarta.

The criteria for determining suburban areas are that these areas spatially intersect with Metropolitan Jakarta Province, namely, South Tangerang, Tangerang, Depok, and Bekasi City. We use the purposive sampling technique to collect data from 82 respondents in South Tangerang, 88 respondents in Tangerang, 82 respondents in Depok, and 80 respondents in Bekasi. The total number of respondents is 332 . We use a questionnaire with an ordinal scale, which were ordered from critical (weight 7) to unimportant (weight 1).

In addition to the approach used by Shiau et al. (2015) and Magee and Scerri (2012), we used a combination of qualitative and quantitative approaches. We examined them with the analytic hierarchy process (AHP) method. Another approach used by Asmelash and Kumar (2019) is the structural equation model (SEM) analysis technique, which develops and examines the validity of tourism sustainability indicators. Following Asmelash and Kumar (2019), we also used SEM techniques with the confirmatory factor analysis (CFA) approach through Amos 22.0 software. CFA is a multivariate analysis method that can be used to confirm whether the measurement model is built according to the one hypothesized. In CFA analysis, the hypothesized model must be valid. Validity refers to the ability of an indicator to measure the desired measurement. The validity of indicators in measuring latent variables is assessed by testing whether all values of the loading factor $(\lambda i)$ are valid by using t-tests for a certain level of confidence. The validity of the indicators was examined using construct reliability (CR) and the average variance extracted (AVE). AVE shows the total variance of the variable that the measurement model can explain. The general model of CFA is as follows.

$$
\mathrm{x}=\Lambda \mathrm{x} \xi+\delta
$$


Where $\mathrm{x}$ is a vector for qx 1 indicator variables, $\Lambda \mathrm{x}$ is a loading factor matrix $(\lambda)$ or a coefficient that shows the relationship of $x$ with qx of size qxn (between indicators are assumed to be correlated; must have common factors) (Solimun et al., 2017), $\xi$ is (ksi) is a vector for latent variables of size $\mathrm{nx} 1$, and $\delta$ is a vector for measurement errors of size qx 1. Evaluation of the CFA model is assessed through the following criteria: (1) large test $\chi^{2}$ values relative to the degree of freedom indicate that the model does not fit the empirical data; (2) root of mean square error of approximation (RMSEA) value smaller than or around 0.10 is an indication of the acceptance of a model; (3) goodness of fit index (GFI) value of $>0.90$ is said to have been supported by empirical data; (4) minimum sample discrepancy function/degree of freedom (CMIN/DF) value of $\geq 5$ indicates a good model (Wheaton et al., 1977); (5) Tucker-Lewis index value of $>0.90$; and (6) comparative fit index (CFI) value of $>0.90$.

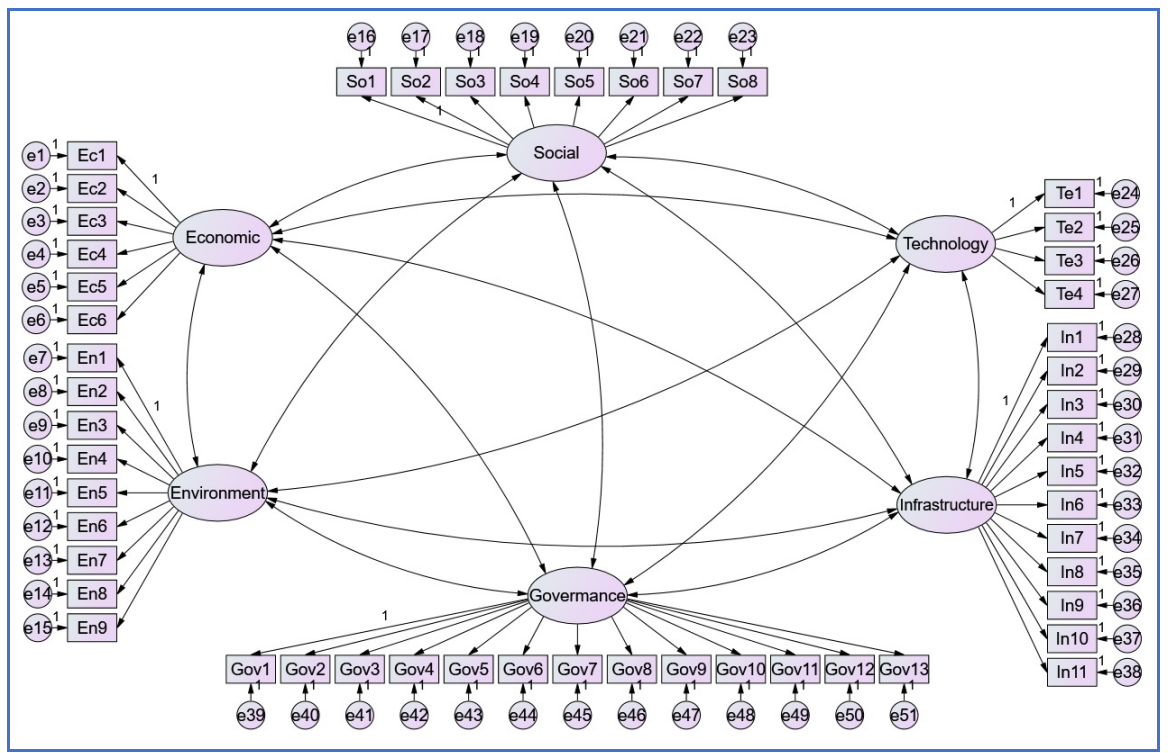

Figure 4. Development of the SRA indicator measurement/validation model

\subsection{Respondent's demographic profile}

In terms of age, the youngest and oldest respondents are 17 and 63 years old, respectively. However, between these age ranges, the age variations of respondents vary greatly. For a more readable frequency distribution, age is presented in the form of certain classes. The most commonly used statistical procedure is first: specify the range ( $\mathrm{r}$ ) of the data as formula (1); second, set the interval class (k) used by Sturges formula (2); and third, specify the interval length of type (c) as shown in formula (3).

$$
\begin{aligned}
& \mathrm{r}=\text { maximum value-minimum value } \\
& \mathrm{k}=1+3,3 \log (\mathrm{n}) \\
& \mathrm{c}=\mathrm{r} / \mathrm{k}
\end{aligned}
$$

Using formula (1), the following information is obtained: the data range (r) is 46 , the interval class ( $\mathrm{k}$ ) as shown in formula (2) is 6.8 , which is rounded into seven categories, and the interval length of the categories (c) is 7 , as obtained by formula (3). From such information, Table 2 presents the frequency distribution in the age classes of respondents. As shown in Figure 
4, respondents in residential areas are dominated by individuals aged 17-23 years old (40\%), and the remaining are 24-30 years old (21\%), 31-37 years old (13\%), 38-44 years old (10\%), 45-51 years old (9\%), and 52-58 years old (4\%). Respondents who are 17-44 years old indicate that residential areas are dominated by the middle-class age range, whom are physically productive.

Table 2. Demographic profile; $\mathrm{n}=332$

\begin{tabular}{ccc}
\hline Respondent profile & Residential area (\%) & Non-residential area (\%) \\
\hline $17-23$ & Age (years) & 49 \\
$24-30$ & 40 & 26 \\
$31-37$ & 21 & 13 \\
$38-44$ & 13 & 6 \\
$45-51$ & 10 & 7 \\
$52-58$ & 9 & 1 \\
$59-65$ & 4 & 0 \\
No answer & 2 & 0 \\
\hline Junior high school & 2 & 2 \\
Senior high school & Education attainment & 51 \\
Diploma/bachelor & 0 & 39 \\
Master's degree & 44 & 4 \\
Doctoral degree & 40 & 0 \\
No answer & 14 & 4 \\
\hline & 2 & \\
\hline Male (\%) & 0 & \\
Nomale (\%) & Gender & \\
\hline
\end{tabular}

Identically, respondents in non-residential areas are the same. A total of $45 \%$ of respondents were dominated by ages $17-23$ years, followed by $24-$ 30 years $(26 \%)$ and $31-37$ years $(12 \%)$, and the remaining $45-51$ years $(7 \%)$ and $52-58$ years $(1 \%)$. However, $3 \%$ of respondents did not indicate their age (Table 2). In aggregate, $42 \%$ of respondents were in the age range of 17 23 years; $26 \%, 24-30$ years; $13 \%, 31-37$ years; $8 \%, 34-44$ years; and $8 \%$, 45-51 years (Table 2). These data confirm that the dominating residents in South Tangerang, Depok, Tangerang, and Bekasi are those within the age range of 20-49 years (Table 3 ).

Table 3. Young population in Suburban Metropolitan Jakarta

\begin{tabular}{crrrr}
\hline \multirow{2}{*}{$\begin{array}{c}\text { Age } \\
\text { (years) }\end{array}$} & \multicolumn{3}{c}{ Suburban Metropolitan Jakarta } \\
\cline { 2 - 5 } & $\begin{array}{r}\text { South } \\
\text { Tangerang }\end{array}$ & Tangerang & Depok & Bekasi \\
\hline $15-19$ & 127.892 & 163.726 & 121,180 & 242.879 \\
$20-24$ & 140.117 & 201.482 & 136,140 & 266.528 \\
$25-29$ & 154.212 & 226.498 & 133,636 & 295.052 \\
$30-34$ & 159.648 & 221.788 & 113,630 & 269.446 \\
$35-39$ & 156.648 & 196.986 & 91,459 & 237.452 \\
$40-44$ & 144.909 & 173.269 & 71,502 & 205.672 \\
\hline Total & 883.426 & 1.183 .749 & 667.547 & 1.517 .029 \\
\hline \% of total & 52,07 & 54,16 & 58,38 & 55,50 \\
population & & & & \\
\hline
\end{tabular}

Source: Local Statistical Bureau, 2019

In aggregate, the respondents' gender was dominated by women $(61 \%$ of the total respondents), and $37 \%$ were men. Table 2 presents information on 
the distribution of respondents' gender frequency. In terms of education level, in residential and non-residential areas in South Tangerang, Depok, Tangerang, and Bekasi City, $47 \%$ of respondents are high school/vocational degree holders, and $40 \%$ have received higher education, either diploma or bachelor degree. Moreover, as many as $9 \%$ of respondents are master's degree holders (Table 2).

The data showed no significant variability between the two regions regarding the education levels in residential and non-residential areas. The distribution of respondents in both areas is dominated by high school/vocational education level, with a $44 \%$ distribution in the region and $51 \%$ in non-residential areas. Significant differences only occur at the level of education in the master's and doctoral degrees. In residential areas, respondents with a master's degree reached $14 \%$ of the total respondents, whereas, in non-residential areas, respondents with the same level of education only comprise $4 \%$ of the total. Some respondents tiered doctoral degrees in the residential area as much as $1 \%$, whereas, in non-residential areas, no respondents have a doctoral degree. The results imply that residential areas seem to be better than those in non-residential areas regarding educational attainment.

\section{RESULTS AND DISCUSSION}

Based on literature studies, we developed the following six parameters of SRA: (1) economy, (2) social, (3) environment, (4) infrastructure, (5) technology, and (6) governance. We argue that infrastructure should be included as one of the SRA's variables because of the spatial conditions of suburban areas, which are different from the situation in rural areas. The needs of suburban communities are commanding (Ningrum et al., 2014), and fast-paced middle-class workers need good-quality infrastructure in supporting all their activities. Although the technology variable deals with "what can we do?", it must translate our understanding into designs and functions that can expand urban and global sustainability. Cities with complex structures, both in terms of social and economic aspects, require integrated responses to overcome problems and challenges that arise (Bugliarello, 2004). According to the United Nations (2015), technology enables more participatory urban governance. It contributes to social inclusion by increasing the availability of means for planners to respond to the need for services. Therefore, technology applications contribute to urban sustainability.

In the context of governance, Jha and Murthy (2000) state that the concept of sustainability has not addressed challenges because it excludes spatial and behavioural aspects and ownership rights in the model. They stated that human behaviour changes in the long run, and they endogenously confirmed ownership rights would change sustainability. Therefore, their valuable suggestions include the need for nonmarket interventions to achieve sustainability, implying that elements of government through governance have become a new issue in sustainability. The government element is vital because it involves whether their policies contribute to sustainable development or not (Evans et al., 2006).

Hence, adding the governance variables is relevant to be developed. In many studies, the nine indicators of good governance are as follows: (1) the participation of all people in the development process; (2) compliance to the rule of law; (3) transparency by the local government; (4) government 
having high responsiveness to the needs (both primary and secondary) of the community; (5) consensus-oriented; (6) fairness; (7) governance being carried out effectively and efficiently; (8) accountability; and (9) strategic vision of regional leaders in bringing their regions to become more prosperous. We use these characteristics as a basis to develop governance indicators.

Furthermore, those six parameters are reflected by 51 indicators (Table 4). After the indicators of each parameter are compiled, the following procedure is to validate those parameters and indicators. In this procedure, the development of path diagrams for each parameter is also included (Figure 4). Furthermore, the 51 indicators are examined by checking the value of the loading factor. A high indicator loading factor value will produce high CR and AVE values. Conversely, a low load factor value will result in a low CR and AVE value, resulting in an invalid parameter. Table 5 results from indicator validation, informing that the indicator has a low loading factor value, and constructed reliability resulted of indicator eliminated are shown in Table 6.

Table 4. Formulation of sustainable residential area indicators

\begin{tabular}{|c|c|c|c|c|}
\hline Parameter & & Indicators & Description & $\begin{array}{l}\text { Annotation and } \\
\text { Citation }\end{array}$ \\
\hline \multirow[t]{6}{*}{ Economic } & 1 & $\begin{array}{l}\text { Economic network } \\
\text { connectivity }\end{array}$ & $\begin{array}{l}\text { Interrelation and combination of } \\
\text { variations in economic activity. The } \\
\text { basic idea is mixtures of activities and } \\
\text { mutually inseparable. }\end{array}$ & Talen (2014) \\
\hline & 2 & Adoption of local labour & $\begin{array}{l}\text { The residential area employs local } \\
\text { people as household assistants, security } \\
\text { guards, etc. }\end{array}$ & Novelty \\
\hline & 3 & Suburban farming & $\begin{array}{l}\text { Residents can conduct small-scale } \\
\text { agricultural activities in the residential } \\
\text { area. It can be formed by using the } \\
\text { front yard and back yard of farming } \\
\text { activities, using pots as a planting } \\
\text { medium. }\end{array}$ & $\begin{array}{l}\text { (Holler and Serra, } \\
\underline{\text { 2012)}}),(\text { Hoornweg and } \\
\underline{\text { Freire, } 2013)}\end{array}$ \\
\hline & 4 & Price & $\begin{array}{l}\text { Affordable price of housing unit in } \\
\text { residential area. }\end{array}$ & $\begin{array}{l}\text { (Hapsariniaty et al. } \\
\underline{2013}),(\text { Handayani, } \\
\underline{2009)}\end{array}$ \\
\hline & 5 & $\begin{array}{l}\text { Value of investment } \\
\text { location of residential } \\
\text { area }\end{array}$ & $\begin{array}{l}\text { Strategic location of residential areas } \\
\text { produces high investment value. }\end{array}$ & $\begin{array}{l}\text { (Hapsariniaty et al., } \\
\underline{\text { 2013) }},(\underline{\text { Serlin and }} \\
\underline{\text { Umilia, 2013) }}\end{array}$ \\
\hline & 6 & $\begin{array}{l}\text { Access to public } \\
\text { facilities (hospital, mall, } \\
\text { sport centre, etc.) }\end{array}$ & $\begin{array}{l}\text { The residential area is adjacent to } \\
\text { public facilities. }\end{array}$ & $\begin{array}{l}\text { (Ding et al., 2010), } \\
\text { ( } \underline{\text { Frenkel et al., 2013 }})\end{array}$ \\
\hline \multirow[t]{6}{*}{ Social } & 7 & $\begin{array}{l}\text { Social participation of } \\
\text { residents }\end{array}$ & $\begin{array}{l}\text { Residents are involved in community } \\
\text { activities. }\end{array}$ & $\begin{array}{l}\text { (Hoornweg and Freire, } \\
\underline{2013}) \text {, Talen (2014) }\end{array}$ \\
\hline & 8 & $\begin{array}{l}\text { Cohesion and social } \\
\text { connection }\end{array}$ & $\begin{array}{l}\text { Some activities can strengthen the } \\
\text { cohesion and social connection of } \\
\text { residents in the residential area. }\end{array}$ & $\begin{array}{l}\text { (Winston and } \\
\underline{\text { Eastaway, 2008), (Le, }} \\
\underline{\text { Ta, and Dang, 2016) }}\end{array}$ \\
\hline & 9 & $\begin{array}{l}\text { Residents' engagement } \\
\text { medium }\end{array}$ & $\begin{array}{l}\text { Recitation, worship services, social } \\
\text { gathering, joint sports, mutual } \\
\text { cooperation, etc. }\end{array}$ & $\begin{array}{l}\text { (Hoornweg and Freire, } \\
\underline{2013}) \text {, Talen }(\underline{2014})\end{array}$ \\
\hline & 10 & $\begin{array}{l}\text { Adoption of local } \\
\text { cultural values }\end{array}$ & $\begin{array}{l}\text { The residential area adopts local } \\
\text { culture, reflected in the area's openness } \\
\text { to local people and appreciation of local } \\
\text { culture. }\end{array}$ & $\begin{array}{l}\text { (Amado et al., 2017), } \\
\text { (Rosenstein, 2011) } \\
(\underline{\text { Grodach, 2017) }}\end{array}$ \\
\hline & 11 & Security & $\begin{array}{l}\text { Reduction of criminal acts (theft, } \\
\text { robbery, muggings, etc.) }\end{array}$ & $\begin{array}{l}\text { (Winston and } \\
\text { Eastaway, 2008) }\end{array}$ \\
\hline & 12 & $\begin{array}{l}\text { Integration of } \\
\text { neighbourhood } \\
\text { association and citizens' }\end{array}$ & $\begin{array}{l}\text { Neighbourhood association and } \\
\text { citizens' association of residential area } \\
\text { merge with neighbourhood association }\end{array}$ & $\begin{array}{l}\text { (Karim and Rashid, } \\
\underline{\text { 2012) }}\end{array}$ \\
\hline
\end{tabular}




\begin{tabular}{|c|c|c|c|c|}
\hline & & $\begin{array}{l}\text { association (intra- and } \\
\text { inter-residential area) }\end{array}$ & $\begin{array}{l}\text { and citizens' association of the local } \\
\text { neighbourhood. }\end{array}$ & \\
\hline & 13 & Health & $\begin{array}{l}\text { The residential area adopts the health } \\
\text { aspects of the environment, both } \\
\text { physically and mentally. }\end{array}$ & $\begin{array}{l}\text { (Liu et al., 2017), } \\
\text { (Barbato et al., 2017) }\end{array}$ \\
\hline & 14 & Residents' hospitality & $\begin{array}{l}\text { Residents greet each other, give a smile } \\
\text { every morning and every time. }\end{array}$ & (Bell, 2007) \\
\hline \multirow[t]{9}{*}{ Environment } & 15 & $\begin{array}{l}\text { The quality of public } \\
\text { open space }\end{array}$ & $\begin{array}{l}\text { Public open spaces are available (parks, } \\
\text { sports facilities, etc.). }\end{array}$ & (Mulliner et al., 2016) \\
\hline & 16 & $\begin{array}{l}\text { Compliance with spatial } \\
\text { planning regulations }\end{array}$ & $\begin{array}{l}\text { The built residential area is compliant } \\
\text { to the spatial plan set by the } \\
\text { government. }\end{array}$ & Novelty \\
\hline & 17 & Low noise pollution & Low motor vehicle traffic. & $\begin{array}{l}\text { Talen (2014), (Winston } \\
\text { and Eastaway, 2008) }\end{array}$ \\
\hline & 18 & $\begin{array}{l}\text { Integrated waste } \\
\text { management }\end{array}$ & $\begin{array}{l}\text { Existence of waste management in the } \\
\text { community ("Bank Sampah") }\end{array}$ & (Suryani, 2016) \\
\hline & 19 & Energy efficiency & $\begin{array}{l}\text { Residents in the residential area } \\
\text { practice energy-saving ways of life. }\end{array}$ & $\begin{array}{l}\text { Talen }(\underline{2014}), \text { (Addanki } \\
\text { and Venkataraman, } \\
\underline{\text { 2017) }}\end{array}$ \\
\hline & 20 & $\begin{array}{l}\text { Preservation of local } \\
\text { ecological and } \\
\text { biodiversity } \\
\text { environments }\end{array}$ & $\begin{array}{l}\text { Maintaining environmental cleanliness, } \\
\text { separating organic/nonorganic waste, } \\
\text { planting trees, etc. }\end{array}$ & $\begin{array}{l}\text { (Hoornweg and Freire, } \\
\underline{2013} \text { ) }\end{array}$ \\
\hline & 21 & $\begin{array}{l}\text { The efficiency of } \\
\text { groundwater use }\end{array}$ & $\begin{array}{l}\text { Groundwater is consumed sufficiently } \\
\text { for household use. Residents are aware } \\
\text { of the importance of efficient } \\
\text { consumption of groundwater. }\end{array}$ & $\begin{array}{l}\text { (Garcia et al., 2013), } \\
\text { (Loubet et al., 2016) }\end{array}$ \\
\hline & 22 & $\begin{array}{l}\text { Involvement into } \\
\text { location }\end{array}$ & Comfort in the residential area. & $\begin{array}{l}\text { (Hoornweg and Freire, } \\
\underline{2013} \text { ) }\end{array}$ \\
\hline & 23 & Water quality & $\begin{array}{l}\text { Clean water is available in adequate } \\
\text { quantity. }\end{array}$ & $\begin{array}{l}\text { Strategic Plan of the } \\
\text { Ministry of Public } \\
\text { Works 2015-2019, } \\
\text { Republic of Indonesia } \\
\text { (Ministry of Public } \\
\text { Works of Republic of } \\
\text { Indonesia, n.d.) }\end{array}$ \\
\hline \multirow[t]{8}{*}{ Infrastructure } & 24 & $\begin{array}{l}\text { The closed gate of a } \\
\text { residential area }\end{array}$ & Open the entrance of a residential area. & (Leisch, 2002) \\
\hline & 25 & $\begin{array}{l}\text { Adoption of local culture } \\
\text { in residential } \\
\text { architecture }\end{array}$ & $\begin{array}{l}\text { Building architecture adopts local } \\
\text { culture. }\end{array}$ & $\begin{array}{l}\text { (Le et al., 2016), (Rid } \\
\text { et al., 2017), (Amado et } \\
\text { al., 2017) }\end{array}$ \\
\hline & 26 & $\begin{array}{l}\text { A speed bump in a } \\
\text { residential area }\end{array}$ & $\begin{array}{l}\text { Existence of a speed bump. The } \\
\text { distance between the speed bump, the } \\
\text { shape and material of the speed bump, } \\
\text { and the speed bump height. }\end{array}$ & $\begin{array}{l}\text { Decree of the Minister } \\
\text { of Transportation No. } \\
\text { KM. 3/1994(Ministry } \\
\text { of Public } \\
\underline{\text { Transportation of }} \\
\underline{\text { Republic of Indonesia, }} \\
\underline{\text { n.d.); (Dinh and }} \\
\text { Kubota, 2013) }\end{array}$ \\
\hline & 27 & $\begin{array}{l}\text { Physical adaptation of } \\
\text { residential buildings to } \\
\text { disaster }\end{array}$ & $\begin{array}{l}\text { House unit in residential area adapts to } \\
\text { physical buildings against disasters. }\end{array}$ & (Renald et al., 2016) \\
\hline & 28 & Security guards & $\begin{array}{l}\text { The existence of a security guard in } \\
\text { residential area. }\end{array}$ & (Leisch, 2002) \\
\hline & 29 & $\begin{array}{l}\text { Distance of residential } \\
\text { area to social facilities } \\
\text { (mosque, } \\
\text { polyclinic/community } \\
\text { health centre/hospital, } \\
\text { school) }\end{array}$ & $\begin{array}{l}\text { Residential areas close to social } \\
\text { facilities (mosques, polyclinics/health } \\
\text { centres/hospitals, schools). }\end{array}$ & (Le et al., 2016) \\
\hline & 30 & $\begin{array}{l}\text { Distance of residential } \\
\text { area to market }\end{array}$ & $\begin{array}{l}\text { Residential areas close to market } \\
\text { facilities. }\end{array}$ & (Le et al., 2016) \\
\hline & 31 & $\begin{array}{l}\text { View of a residential } \\
\text { area }\end{array}$ & $\begin{array}{l}\text { The residential area provides a } \\
\text { refreshing view. }\end{array}$ & $\begin{array}{l}\text { (Hapsariniaty et al. } \\
\underline{2013} \text { ) }\end{array}$ \\
\hline
\end{tabular}




\begin{tabular}{|c|c|c|c|c|}
\hline & 32 & Accessibility for people & Accessibility in residential areas & (Le et al., 2016) \\
\hline & 33 & Access to workplace & The housing area needs to be close to & (Mulliner et al., 2016) \\
\hline & 34 & Street lighting & $\begin{array}{l}\text { access places of work. } \\
\text { The existence of street lighting that } \\
\text { includes the number and quality. }\end{array}$ & (Mulliner et al., 2016) \\
\hline \multirow[t]{4}{*}{ Technology } & 35 & $\begin{array}{l}\text { Internet connection and } \\
\text { its speed }\end{array}$ & $\begin{array}{l}\text { Availability of internet network with } \\
\text { quality connections. }\end{array}$ & $\begin{array}{l}\text { (Kummitha and } \\
\text { Crutzen, 2017) }\end{array}$ \\
\hline & 36 & Public transportation & $\begin{array}{l}\text { Public transportation facilities are } \\
\text { available that can be accessed by } \\
\text { residents in the residential area. }\end{array}$ & $\begin{array}{l}\text { (Miralles-Guasch and } \\
\text { Domene, 2010), Talen } \\
\text { (2014) }\end{array}$ \\
\hline & 37 & $\begin{array}{l}\text { Social media group } \\
\text { (intra- and inter- } \\
\text { residents) }\end{array}$ & $\begin{array}{l}\text { Residents are incorporated into } \\
\text { WhatsApp, Line group, etc., in each } \\
\text { neighbourhood association and } \\
\text { citizens' association. }\end{array}$ & Novelty \\
\hline & 38 & CCTV cameras & $\begin{array}{l}\text { Housing areas need to be equipped with } \\
\text { CCTV cameras. }\end{array}$ & (Leisch, 2002) \\
\hline \multirow[t]{13}{*}{ Governance } & 39 & Program innovation & The local government designs a & (Hoornweg and Freire, \\
\hline & & & $\begin{array}{l}\text { breakthrough program related to the } \\
\text { housing and residential area. }\end{array}$ & $\begin{array}{l}\text { 2013), (Addanki and } \\
\text { Venkataraman, 2017) }\end{array}$ \\
\hline & 40 & $\begin{array}{l}\text { The vision of local } \\
\text { leaders about the } \\
\text { residential area }\end{array}$ & $\begin{array}{l}\text { There is a clear vision of local leaders } \\
\text { in the governance of housing and } \\
\text { residential area. }\end{array}$ & $\begin{array}{l}\text { (Hoornweg and Freire, } \\
\text { 2013), (Priyarsono, } \\
\underline{2017}),(\text { Addanki and } \\
\text { Venkataraman, 2017) }\end{array}$ \\
\hline & 41 & $\begin{array}{l}\text { Participation in the } \\
\text { planning process }\end{array}$ & $\begin{array}{l}\text { The government provides a medium for } \\
\text { citizen participation in supporting } \\
\text { housing and residential area } \\
\text { governance. }\end{array}$ & (Rid et al., 2017) \\
\hline & 42 & $\begin{array}{l}\text { Permitting of residential } \\
\text { transaction }\end{array}$ & $\begin{array}{l}\text { Permitting is accessible, concise and } \\
\text { fast, and without illegal fees. }\end{array}$ & $\begin{array}{l}\text { (Buchori and Sugiri, } \\
\text { 2016), (Rid et al.., } \\
\text { 2017) }\end{array}$ \\
\hline & 43 & Waste recycling program & $\begin{array}{l}\text { The government initiates a waste } \\
\text { recycling program and its management. }\end{array}$ & Talen (2014) \\
\hline & 44 & $\begin{array}{l}\text { Proactive neighbourhood } \\
\text { association and citizens' } \\
\text { association }\end{array}$ & $\begin{array}{l}\text { The proactivity of neighbourhood } \\
\text { association and citizens' association } \\
\text { institutions in informing and publishing } \\
\text { local government policies, especially } \\
\text { citizenship services. }\end{array}$ & Novelty \\
\hline & 45 & $\begin{array}{l}\text { Neighbourhood } \\
\text { association and citizens } \\
\text { association facilitate } \\
\text { formatting social media } \\
\text { communication (intra- } \\
\text { and inter-residents) }\end{array}$ & WhatsApp, Line group, etc. & Novelty \\
\hline & 46 & $\begin{array}{l}\text { Coordination in } \\
\text { neighbourhood } \\
\text { association and citizens' } \\
\text { association related to the } \\
\text { residential area }\end{array}$ & It is implemented in regular meetings. & World Bank (2017) \\
\hline & 47 & $\begin{array}{l}\text { A credible commitment } \\
\text { of the local government }\end{array}$ & $\begin{array}{l}\text { Proactivity in socialising government } \\
\text { programs and its activities and } \\
\text { monitoring residential development. }\end{array}$ & $\begin{array}{l}(\underline{\text { Ostrom, 1990) }}) \\
\text { (World Bank, } \underline{2017})\end{array}$ \\
\hline & 48 & $\begin{array}{l}\text { Design activities that can } \\
\text { strengthen social } \\
\text { connections between } \\
\text { residents }\end{array}$ & $\begin{array}{l}\text { The design of activities initiated by the } \\
\text { local government such as youth } \\
\text { association activities (karang taruna), } \\
\text { women's association activities, } \\
\text { cooperation (gotong royong), etc. }\end{array}$ & (Le et al., 2016) \\
\hline & 49 & $\begin{array}{l}\text { Suburban farming } \\
\text { incentives }\end{array}$ & $\begin{array}{l}\text { The local government provides } \\
\text { incentives for citizens to develop urban } \\
\text { farming. }\end{array}$ & Novelty \\
\hline & 50 & $\begin{array}{l}\text { Certification for } \\
\text { sustainable systems }\end{array}$ & $\begin{array}{l}\text { The government needs to develop a } \\
\text { certification of sustainable residential } \\
\text { areas for housing developers. }\end{array}$ & (Rid et al., 2017) \\
\hline
\end{tabular}


Table 5. Low and eliminated indicator load factor values

\begin{tabular}{|c|c|c|}
\hline $\begin{array}{l}\text { Indicator } \\
\text { code }\end{array}$ & Construct/indicator & Loading factor \\
\hline \multicolumn{3}{|c|}{ Economic } \\
\hline $\mathrm{Ec}_{1}$ & Economic network connectivity & 0.075 \\
\hline $\mathrm{Ec}_{2}$ & Adoption of local labour & 0.284 \\
\hline $\mathrm{Ec}_{3}$ & Small-scale suburban farming & 0.407 \\
\hline \multicolumn{3}{|c|}{ Social } \\
\hline $\mathrm{So}_{1}$ & Social participation of residents & 0.476 \\
\hline $\mathrm{So}_{2}$ & Cohesion and social connection & 0.598 \\
\hline $\mathrm{So}_{3}$ & Residents' engagement medium & 0.715 \\
\hline $\mathrm{So}_{4}$ & Adoption of local cultural values & 0.562 \\
\hline $\mathrm{So}_{6}$ & $\begin{array}{l}\text { Integration of neighbourhood association and citizens' association } \\
\text { (intra- and inter-residential area) }\end{array}$ & 0.468 \\
\hline \multicolumn{3}{|c|}{ Infrastructure } \\
\hline $\operatorname{In}_{1}$ & The closed gate of the residential area & 0.314 \\
\hline $\operatorname{In}_{2}$ & Adoption of local culture in residential architecture & 0.140 \\
\hline $\mathrm{In}_{3}$ & A speed bump in the residential area & 0.203 \\
\hline $\mathrm{In}_{4}$ & Physical adaptation of residential buildings to disaster & 0.620 \\
\hline $\operatorname{In}_{7}$ & The distance of residential area to market & 0.618 \\
\hline \multicolumn{3}{|c|}{ Technology } \\
\hline $\mathrm{Te}_{3}$ & Social media group (intra- and inter-residents) & 0.459 \\
\hline
\end{tabular}

Table 6. Construct reliability (result of indicator eliminated)

\begin{tabular}{lrrrl}
\hline \multicolumn{1}{c}{ Construct } & \multicolumn{1}{c}{ CR } & \multicolumn{1}{c}{ AVE } & \multicolumn{2}{c}{ Standardised } \\
Regression Weights & Annotation \\
\hline Economic & 0.737 & 0.489 & 0.691 & Established \\
Environmental & 0.916 & 0.550 & 0.737 & Established \\
Social & 0.767 & 0.525 & 0.722 & Established \\
Infrastructure & 0.844 & 0.521 & 0.719 & Established \\
Technology & 0.732 & 0.480 & 0.689 & Established \\
Governance & 0.970 & 0.713 & 0.843 & Established \\
\hline
\end{tabular}

Based on the 51 indicators, we only have 36 that could be considered as a measure of the SRA (Table 7, Figure 5). Regarding the number of selected indicators, (Sors, 2001) states that, for a number of indicators, ranging from 20 to 50 is sufficient to measure sustainability.

\begin{tabular}{|c|c|c|}
\hline $\begin{array}{c}\text { Indicator } \\
\text { code }\end{array}$ & Construct/indicator & Loading factor \\
\hline \multicolumn{3}{|c|}{ Economic } \\
\hline $\mathrm{Ec}_{4}$ & Price & 0.596 \\
\hline $\mathrm{Ec}_{5}$ & Value of investment location of a residential area & 0.624 \\
\hline $\mathrm{Ec}_{6}$ & Access to public facilities (hospital, mall, sports centre) & 0.850 \\
\hline \multicolumn{3}{|c|}{ Social } \\
\hline $\mathrm{So}_{5}$ & Security & 0.626 \\
\hline $\mathrm{So}_{7}$ & Health & 0.770 \\
\hline $\mathrm{So}_{8}$ & Hospitality & 0.768 \\
\hline \multicolumn{3}{|c|}{ Environment } \\
\hline $\mathrm{En}_{1}$ & The quality of public open space & 0.725 \\
\hline $\mathrm{En}_{2}$ & Compliance with spatial planning regulations & 0.568 \\
\hline $\mathrm{En}_{3}$ & Low noise pollution & 0.617 \\
\hline $\mathrm{En}_{4}$ & Integrated waste management & 0.568 \\
\hline $\mathrm{En}_{5}$ & Energy efficiency & 0.763 \\
\hline $\mathrm{En}_{6}$ & Preservation of local ecological and biodiversity environments & 0.844 \\
\hline
\end{tabular}




\begin{tabular}{|c|c|c|}
\hline $\mathrm{En}_{7}$ & The efficiency of groundwater use & 0.828 \\
\hline $\mathrm{En}_{8}$ & Involvement into location & 0.725 \\
\hline \multirow[t]{2}{*}{$\mathrm{En}_{9}$} & Clean water & 0.780 \\
\hline & Infrastructure & \\
\hline $\mathrm{In}_{5}$ & Security guards & 0.642 \\
\hline $\operatorname{In}_{6}$ & $\begin{array}{l}\text { The distance of residential area to social facilities (mosque, } \\
\text { polyclinic/community health centre/hospital, school) }\end{array}$ & 0.749 \\
\hline $\operatorname{In}_{8}$ & View of the residential area & 0.662 \\
\hline $\mathrm{In}_{9}$ & Accessibility for people with disabilities & 0.739 \\
\hline \multirow[t]{2}{*}{$\operatorname{In}_{11}$} & Street lighting & 0.804 \\
\hline & Technology & \\
\hline $\mathrm{Te}_{1}$ & The internet connection and its speed & 0.733 \\
\hline $\mathrm{Te}_{2}$ & Public vehicle & 0.747 \\
\hline \multirow[t]{2}{*}{$\mathrm{Te}_{4}$} & CCTV cameras & 0.586 \\
\hline & Governance & \\
\hline $\operatorname{Gov}_{1}$ & Program innovation & 0.816 \\
\hline $\mathrm{Gov}_{2}$ & The vision of local leaders about the residential area & 0.889 \\
\hline $\mathrm{Gov}_{3}$ & Participation in the planning process & 0.911 \\
\hline $\mathrm{Gov}_{4}$ & Permitting of residential transactions & 0.829 \\
\hline $\mathrm{Gov}_{5}$ & Waste recycling program & 0.866 \\
\hline $\mathrm{Gov}_{6}$ & Proactive neighbourhood association and citizens' association & 0.846 \\
\hline $\mathrm{Gov}_{7}$ & $\begin{array}{l}\text { Neighbourhood association and citizens' association facilitate } \\
\text { formatting social media communication (intra- and inter-residents) }\end{array}$ & 0.801 \\
\hline $\mathrm{Gov}_{8}$ & $\begin{array}{l}\text { Coordination in neighbourhood association and citizens' } \\
\text { association related to the residential area }\end{array}$ & 0.860 \\
\hline $\mathrm{Gov}_{9}$ & Credible commitment of the local government & 0.918 \\
\hline $\operatorname{Gov}_{10}$ & $\begin{array}{l}\text { The design of activities that can strengthen social connections } \\
\text { between residents }\end{array}$ & 0.828 \\
\hline $\operatorname{Gov}_{11}$ & Suburban small-scale farming incentives & 0.838 \\
\hline $\operatorname{Gov}_{12}$ & Certification for sustainable systems & 0.716 \\
\hline $\operatorname{Gov}_{13}$ & Transparency & 0,837 \\
\hline
\end{tabular}

Furthermore, we evaluate the overall model, aiming to assess whether the model has validity or not. Table 8 presents the results of the model test. Results of the first evaluation reveal that two components still have not produced a value according to established criteria, indicating that the model cannot be the best. In generating a better model, we modified the model based on Arbuckle's (1996) theory, which discusses how to modify the model by looking at the resulting modification indices. Arbuckle (1996) explained that the modification indices provided several recommendations for adding links between indicators to reduce the chi-square value to make the model more fit. After the modification, all the criteria are a good fit. Likewise, the criteria for GFI, TLI, and CFI, which were initially only able to achieve a marginal fit, increased to a good fit after the modification. 


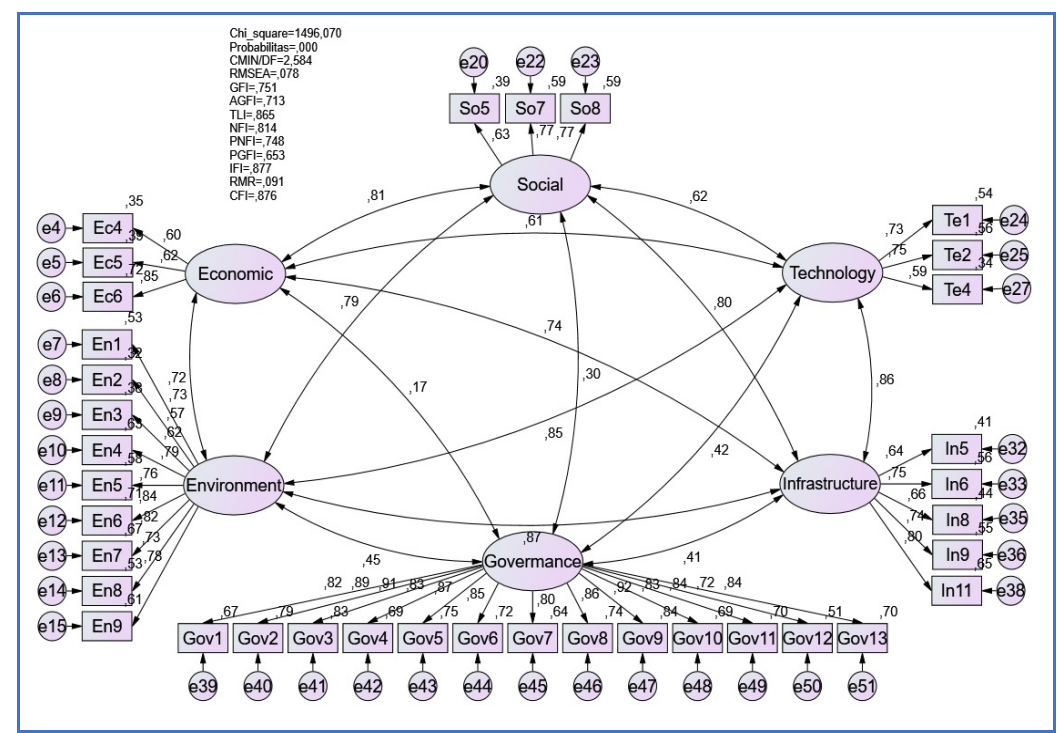

Figure 5. Selected SRA's indicator

Achieving residential area sustainability in suburban areas becomes critical when associated with the fact that more than $70 \%$ of the land in this area is used for housing and residential areas, both in residential areas built by developers and built individually by the community. The SRA will ensure regional sustainability. Therefore, in the economic pillar, for example, the price of a house in a residential area should be affordable for society. In addition, residential areas must also have access to public facilities (hospitals, malls, sports centres, etc.). Here, these findings clarify the classic theory about von Thunen's economic location.

In terms of the CCTV camera criteria, this becomes the best criteria assessed by stakeholders in realizing SRA. CCTV cameras are complementary infrastructure of a residential area. This facility plays a role in efforts to minimize incidents of criminality. Many studies agree that people's preference to live in residential areas is due to a sense of security. The purpose of safety is manifested in the form of completeness of supporting facilities, one of which is the presence of CCTV cameras (Leisch, 2002). In the context of SDGs, the fulfilment of CCTV cameras in residential areas supports the 16th goal, that is peace, justice, and resilient institutions. Thus, the following are three related indicators: the decrease in the number of murder crimes in the past year, the decrease in the proportion of the population who are victims of violent crimes, and the increasing proportion of people who feel safe walking alone in the area of residence.

In infrastructure aspects, public facility availability (roads, waterways, public lighting tools, landfills, etc.) becomes the best criteria that policymakers must choose in developing sustainable housing areas. Lastly, in the technology aspect, the availability of internet networks should get the attention of policymakers because this criteria obtains the highest degree of interest compared to other measures.

We would say that the model could be considered a system of interrelated systems to one another. In some literature reviews, the structure consists of the elements that are related to each other. In contrast, a system is a group of entities that interact or are interconnected to form a unity. The system is characterized by (1) a collection of materials and processes that together form several functional groups or uses and (2) the linkages of several processes characterised by causal trajectories (Grant 1986 in Solimun et al., 2017). 
Table 8. Model evaluation result

\begin{tabular}{|c|c|c|c|c|c|}
\hline \multirow{2}{*}{ Criteria } & \multirow{2}{*}{ Cut-off Value } & \multicolumn{2}{|c|}{ First-stage evaluation } & \multicolumn{2}{|c|}{$\begin{array}{l}\text { Second-stage evaluation } \\
\text { (model modification) }\end{array}$} \\
\hline & & $\begin{array}{c}\text { Estimation } \\
\text { result }\end{array}$ & Annotation & $\begin{array}{c}\text { Estimation } \\
\text { result }\end{array}$ & Annotation \\
\hline Chi-square $\left(\chi^{2}\right)$ & 636.087 & 1496.070 & Bad fit & 509.028 & Good fit \\
\hline Significance probability & $\geq 0.05$ & 0.000 & Bad fit & 0.069 & Good fit \\
\hline RMSEA & $\leq 0.08$ & 0.078 & Good fit & 0.020 & Good fit \\
\hline GFI & $\geq 0.90$ & 0.751 & Marginal fit & 0.905 & Good fit \\
\hline $\mathrm{CMIN/DF}$ & $\leq 3.00$ & 2.584 & Good fit & 1.099 & Good fit \\
\hline TLI & $\geq 0.95$ & 0.865 & Marginal fit & 0.992 & Good fit \\
\hline CFI & $\geq 0.95$ & 0.876 & Marginal fit & 0.994 & Good fit \\
\hline
\end{tabular}

By considering the results of the evaluation of the model, we can state that the built model can measure the SRA. All constructs consisting of economic, social, environmental, infrastructure, technology, and governance can be considered as new interrelated parameters in measuring SRA. A summary of indicators based on extensive literature studies can produce parameters and indicators that are more comprehensive than those of previous studies.

\section{CONCLUSION}

The concept of "triple bottom lines" (economic, social, and environmental) cannot sufficiently answer urban sustainability challenges, particularly in specific cases such as residential areas. We generate 51 SRA indicators grouped into economic, social, environmental, infrastructure, technology, and governance parameters based on extensive literature studies. Adding infrastructure, technology, and governance, we find that those parameters could answer the sustainability challenges of residential areas in Suburban Metropolitan Jakarta. We argue that infrastructure responds to the challenges of urban-suburban communities characterised by middle-class commuters who require a high speed of service and accessibility. Technology responds to sustainability challenges in an era of disruption in a complex urban context, especially the demand for services. Furthermore, governance provides the policy direction that government must take to achieve sustainable development.

By using SEM CFA, 36 selected indicators were produced that could be used as measurements to assess the SRA. The measurement model obtained also produces a robust and compact model because the model parameters are estimated simultaneously. This study provides that the model could be considered a structure and system that enhances the SRA. Although infrastructure, technology, and governance variables are built for the context of the SRA, they could be a novelty idea for further studies related to the development of sustainability, both for regional and sectoral and even for global contexts. In this study, some indicators were deemed useless at the policy level due to difficulties in using concrete policy. Nevertheless, as an empirical discourse, these indicators can be an initial thinking point for making them more operational.

In responding to technological change (disruption), further research can be conducted by developing extensive indicators within the technological parameter. However, improvement and even extension of indicators in other constructs are still possible in the future because some indicators in the economic construct produce unsatisfactory values. In terms of sampling 
techniques, this study uses nonprobability sampling. The limitation of the sampling technique is yielding samples that are less representative of the population. After all, the procedures include our subjectivity. The reason for this is that a complete list of population members to be sampled is not available. Therefore, we recommend using probability sampling to produce better estimates for future studies.

In terms of its application in public policy formulation, the results of this research are helpful in the efforts to improve the draft concept of sustainable housing in Indonesia. Moreover, the study improved the various indicators devised by the National Standardization Agency of the Republic of Indonesia in 2014.

\section{ACKNOWLEDGMENT}

This article is part of a dissertation on Regional and Rural Development Planning Sciences, Bogor Agricultural University, under the supervision of Prof. Dr. Dominicus Savio Priyarsono, Prof. Dr. Akhmad Fauzi, and Dr. Arya Hadi Dharmawan. The author wishes to thank preliminary reviewers of this article.

\section{REFERENCES}

Addanki, S. C., \& Venkataraman, H. (2017). "Greening the Economy: A Review of Urban Sustainability Measures for Developing New Cities". Sustainable Cities and Society, 32, 1-8. doi: https://doi.org/10.1016/j.scs.2017.03.009.

Amado, M. P., Ramalhete, I., Amado, A. R., \& Freitas, J. C. (2017). "Inclusive Housing Program: The Case of Oé-Cusse Region in East Timor". Frontiers of Architectural Research, 6(1), 74-88. doi: https://doi.org/10.1016/j.foar.2016.12.001.

Andrada, A. F. S. (2017). "Understanding Robert Lucas (1967-1981): His Influence and Influences”. EconomiA, 18(2), 212-228. doi: https://doi.org/10.1016/j.econ.2016.09.001.

Arbuckle, J. L. (1996). "Full Information Estimation in the Presence of Incomplete Data". In G. A. Marcoulides and R. E. Schumacker (Eds.), Advanced Structural Equation Modeling: Issues and Techniques (pp. 243-277). Mahwah, New Jersey: Lawrence Erlbaum Associates, Inc.

Arwati, D., \& Latif, D. V. (2019). "Public Trust and Financial Transparency of E-Government Implementation in Bandung City". Journal of Economics, Business, and Government Challenges, 2(2), 136-143.

Asmelash, A. G., \& Kumar, S. (2019). “Assessing Progress of Tourism Sustainability: Developing and Validating Sustainability Indicators". Tourism Management, 71, 67-83. doi: https://doi.org/10.1016/j.tourman.2018.09.020.

Aulia, D. N. (2016). "A Framework for Exploring Livable Community in Residential Environment. Case Study: Public Housing in Medan, Indonesia". Procedia - Social and Behavioral Sciences, 234, 336-343. doi: https://doi.org/10.1016/j.sbspro.2016.10.250.

Barbato, A., Civenti, G., \& D'Avanzo, B. (2017). "Community Residential Facilities in Mental Health Services: A Ten-Year Comparison in Lombardy". Health Policy, 121(6), 623-628. doi: https://doi.org/10.1016/j.healthpol.2017.03.012.

Bell, D. (2007). "The Hospitable City: Social Relations in Commercial Spaces". Progress in Human Geography, 31(1), 7-22. doi: https://doi.org/10.1177/0309132507073526.

BSN. (2004). "Procedure for Planning a Housing Environment in Urban". (SNI: 03-17332004).

Buchori, I., \& Sugiri, A. (2016). “An Empirical Examination of Sustainable Metropolitan Development in Semarang City, Indonesia". Australian Planner, 53(3), 163-177. doi: https://doi.org/10.1080/07293682.2016.1151905.

Bugliarello, G. (2004). "Urban Sustainability: Science, Technology, and Policies". Journal of Urban Technology, 11(2), 1-11. doi: https://doi.org/10.1080/10630730412331297288.

Clark, G. E. (2007). "Unsustainable Suburbia". Environment: Science and Policy for Sustainable Development, 49(8), 3-5. doi: https://doi.org/10.3200/ENVT.49.8.3-5. 
Deng, Q., Li, E., \& Zhang, P. (2020). "Livelihood Sustainability and Dynamic Mechanisms of Rural Households out of Poverty: An Empirical Analysis of Hua County, Henan Province, China”. Habitat International, 99, $102160 . \quad$ doi: https://doi.org/10.1016/j.habitatint.2020.102160.

Ding, W., Zheng, S., \& Guo, X. (2010). "Value of Access to Jobs and Amenities: Evidence from New Residential Properties in Beijing". Tsinghua Science and Technology, 15(5), 595-603.

Dinh, D. D., \& Kubota, H. (2013). "Speeding Behavior on Urban Residential Streets with a $30 \mathrm{~km} / \mathrm{h}$ Speed Limit under the Framework of the Theory of Planned Behavior". Transport Policy, 29, 199-208. doi: https://doi.org/10.1016/j.tranpol.2013.06.003.

Elhadary, Y. A. E., Samat, N., \& Obeng-Odoom, F. (2013). "Development at the Peri-Urban Area and Its Impact on Agricultural Activities: An Example from the Seberang Perai Region, Penang State, Malaysia”. Agroecology and Sustainable Food Systems, 37(7), 834856. doi: https://doi.org/10.1080/21683565.2013.797950.

Elkington, J. (1997). Cannibals with Forks - The Triple Bottom Line of 21st Century Business. Stoney Creek, CT: New Society Publishers.

Evans, B., Joas, M., Sundback, S., \& Theobald, K. (2006). "Governing Local Sustainability". Journal of Environmental Planning and Management, 49(6), 849-867. doi: https://doi.org/10.1080/09640560600946875.

Finco, A., \& Nijkamp, P. (2001). "Pathways to Urban Sustainability". Journal of Environmental Policy \& Planning, 3(4), 289-302. doi: https://doi.org/10.1002/jepp.94.

Frenkel, A., Bendit, E., \& Kaplan, S. (2013). "Residential Location Choice of KnowledgeWorkers: The Role of Amenities, Workplace and Lifestyle". Cities, 35, 33-41. doi: https://doi.org/10.1016/j.cities.2013.06.005.

Garcia, X., Ribas, A., Llausàs, A., \& Saurí, D. (2013). "Socio-Demographic Profiles in Suburban Developments: Implications for Water-Related Attitudes and Behaviors along the Mediterranean Coast". Applied Geography, 41, 46-54. doi: https://doi.org/10.1016/j.apgeog.2013.03.009.

Grodach, C. (2017). "Urban Cultural Policy \& Creative City Making”. Cities, 68, 82-91. doi: https://doi.org/10.1016/j.cities.2017.05.015.

Handayani, A. W. (2009). "Attribute Patterns Affecting Consumer Preferences in Buying a House in Depok District, Sleman Regency, Yogyakarta in 2008”. Economic and Business Journal (JEB), 3(2), 91-105.

Hapsariniaty, A. W., Sidi, B. D., \& Nurdini, A. (2013). "Comparative Analysis of Choosing to Live in Gated Communities: A Case Study of Bandung Metropolitan Area". Procedia Social and Behavioral Sciences, 101, 394-403. doi: https://doi.org/10.1016/j.sbspro.2013.07.213.

Holler, T., \& Serra, A. (2012). "A Vision of Suburban Sustainability: The Long Island Radically Rezoned Project". Metropolitan Sustainability: Understanding and Improving the Urban Environment, 697-720. doi: https://doi.org/10.1533/9780857096463.6.697.

Hoornweg, D., \& Freire, M. (2013). "Building Sustainability in an Urbanizing World”. World Bank Publications, 216.

Huang, Y., \& Jiang, L. (2009). "Housing Inequality in Transitional Beijing”. International Journal of Urban and Regional Research, 33(4), 936-956.

Hwang, S. (2015). "Residential Segregation, Housing Submarkets, and Spatial Analysis: St. Louis and Cincinnati as a Case Study". Housing Policy Debate, 25(1), 91-115. doi: https://doi.org/10.1080/10511482.2014.934703.

Jha, R., \& Murthy, K. V. B. (2000). "Sustainability-Property Rights, Behavior, and Economic Growth". Paper at the World Congress on Managing and Measuring Sustainability, Ontario.

Ji, X., Ren, J., \& Ulgiati, S. (2019). "Towards Urban-Rural Sustainable Cooperation: Models and Policy Implication". Journal of Cleaner Production, 213, 892-898. doi: https://doi.org/10.1016/i.jclepro.2018.12.097.

Karim, H. A., \& Rashid, S. M. A. (2012). "Participation in Rukun Tetangga in PKNS Flats as Human Responses to Community Safety". Procedia - Social and Behavioral Sciences, 49, 310-318. doi: https://doi.org/10.1016/j.sbspro.2012.07.029.

Kerr, J. (2008). "Behind Housing Fences: Middle-Class Villages in Malang, East Java [In Indonesian]". Muhammadiyah Malang Universirty.

Kummitha, R. K. R., \& Crutzen, N. (2017). "How Do We Understand Smart Cities? An Evolutionary Perspective". Cities, 67(July 2016), 43-52. doi: https://doi.org/10.1016/j.cities.2017.04.010.

Le, L. H., Ta, A. D., \& Dang, H. Q. (2016). "Building up a System of Indicators to Measure Social Housing Quality in Vietnam". Procedia Engineering, 142, 115-122. doi: https://doi.org/10.1016/i.proeng.2016.02.021.

Leisch, H. (2002). "Gated Communities in Indonesia". Cities, 19(5), 341-350. doi: 
https://doi.org/10.1016/S0264-2751(02)00042-2.

Liu, Y., Dijst, M., Faber, J., Geertman, S., \& Cui, C. (2017). "Healthy Urban Living: Residential Environment and Health of Older Adults in Shanghai". Health and Place, 47, 80-89. doi: https://doi.org/10.1016/j.healthplace.2017.07.007.

Liu, Z., \& Liu, L. (2016). "Characteristics and Driving Factors of Rural Livelihood Transition in the East Coastal Region of China: A Case Study of Suburban Shanghai". Journal of Rural Studies, 43,145-158. doi: https://doi.org/10.1016/j.jrurstud.2015.12.008.

Local Statistical Bureau. (2019). "South Tangerang Municipality in Figure, Tangerang Municipality in Figure, Depok Municipality in Figure, Bekasi Municipality in Figure.”. Retrieved from https://tangselkota.bps.go.id/publication.html on March 27, 2019.

Loubet, P., Roux, P., Guérin-Schneider, L., \& Bellon-Maurel, V. (2016). "Life Cycle Assessment of Forecasting Scenarios for Urban Water Management: A First Implementation of the WaLA Model on Paris Suburban Area". Water Research, 90, 128140. doi: https://doi.org/10.1016/j.watres.2015.12.008.

Magee, L., \& Scerri, A. (2012). "From Issues to Indicators: Developing Robust Community Sustainability Measures". Local Environment: The International Journal of Justice and Sustainability, 17(8), 915-933. doi: https://doi.org/10.1080/13549839.2012.714755.

Ministry of Public Transportation of Republic of Indonesia. n.d. (1994) "Decree of Minister of Public Transportation No. KM. 3/1994 on Road User Control and Safety Device."

Ministry of Public Works of Republic of Indonesia. n.d. (2019) "Strategic Plan of the Ministry of Public Works 2015-2019". Retrieved from https://peraturan.bpk.go.id/Home/Details/128174/permen-pupr-no-18prtm2019-tahun2019 on July 2, 2021.

Miralles-Guasch, C., \& Domene, E. (2010). "Sustainable Transport Challenges in a Suburban University: The Case of the Autonomous University of Barcelona". Transport Policy, 17(6), 454-463. doi: https://doi.org/10.1016/j.tranpol.2010.04.012.

Mulliner, E., Malys, N., \& Maliene, V. (2016). "Comparative Analysis of MCDM Methods for the Assessment of Sustainable Housing Affordability". Omega (United Kingdom), 59, 146-156. doi: https://doi.org/10.1016/j.omega.2015.05.013.

Neckerman, K. M., Lovasi, G. S., Davies, S., Purciel, M., Quinn, J., Feder, E., Raghunath, N., Wasserman, B., \& Rundle, A. (2009). "Disparities in Urban Neighborhood Conditions: Evidence from GIS Measures and Field Observation in New York City". Journal of Public Health Policy, 30(1), S264-S285. doi: https://doi.org/10.1057/jphp.2008.47.

Newman, B. J., Johnson, J., \& Lown, P. L. (2013). “The 'Daily Grind': Work, Commuting, and Their Impact on Political Participation". American Politics Research, 42(1), 141-170. doi: https://doi.org/10.1177/1532673X13498265.

Ningrum, V., Putri, I. A. P., \& Ekaputri, A. D. (2014). "Middle Class Youth, Lifestyle, and Political Involvement: Urban Empirical Study in Jabodetabek [In Indonesian]". Jurnal Kependudukan Indonesia, 9(2), 1-20.

Olsson, J., Hilding-Rydevik, T., Aalbu, H., \& Bradley, K. (2004). "Indicators for Sustainable Development". Discussion Paper for European Regional Network on Sustainable Developmen, Nordic Centre for Spatial Development., Cardiff, Stockholm, pp. 23-24.

Ostrom, E. (1990). Governing the Commons: The Evolution of Institutions for Collective Action. Cambridge: Cambridge University Press.

Pakzad, E., \& Salari, N. (2018). "Measuring Sustainability of Urban Blocks: The Case of Dowlatabad, Kermanshah City". Cities, 75, 90-100. doi: https://doi.org/10.1016/j.cities.2018.01.005.

Priyarsono, D. S. (2017). "To Develop from The Periphery: A Review From the Perspective of Regional Economics [In Indonesian]". Journal of Regional and Rural Development Planning, 1(1), 42-52.

Ragusett, J. M. (2014). "Is Urban Sprawl Good for Minorities?". Housing Policy Debate, 24(2), 335-363. doi: https://doi.org/10.1080/10511482.2013.835333.

Renald, A., Tjiptoherijanto, P., Suganda, E., \& Djakapermana, R. D. (2016). "Toward Resilient and Sustainable City Adaptation Model for Flood Disaster Prone City: Case Study of Jakarta Capital Region”. Procedia - Social and Behavioral Sciences, 227, 334-340. doi: https://doi.org/10.1016/j.sbspro.2016.06.079.

Rid, W., Lammers, J., \& Zimmermann, S. (2017). "Analysing Sustainability Certification Systems in the German Housing Sector from a Theory of Social Institutions". Ecological Indicators, 76, 97-110. doi: https://doi.org/10.1016/j.ecolind.2016.12.022.

Rosenstein, C. (2011). "Cultural Development and City Neighborhoods". City, Culture and Society, 2(1), 9-15. doi: https://doi.org/10.1016/j.ccs.2011.02.002.

Schram, A. J. H. C. (1991). Voter Behavior in Economics Perspective. Paris: Springer-Verlag.

Seghezzo, L. (2009). "The Five Dimensions of Sustainability”. Environmental Politics, 18(4), 539-556. doi: https://doi.org/10.1080/09644010903063669. 
Serlin, M. A., \& Umilia, E. (2013). "The Factors that influence the community in choosing the location of Hunian Peri Urban Surabaya in sidoarjo [In Indonesian]”. Jurnal Teknik Pomits, 2(2), C-143-C-148.

Shiau, T.-A., Huang, M.-W., \& Lin, W.-Y. (2015). "Developing an Indicator System for Measuring Taiwan's Transport Sustainability”. International Journal of Sustainable Transportation, 9(2), 81-92. doi: https://doi.org/10.1080/15568318.2012.738775.

Solimun, Fernandes, A. A. R., \& Nurjannah. (2017). Multivariate Statistical Method: Structural Equation Modeling Based on WarpPLS. Malang: UB Press.

Sors, J. C. (2001). "Measuring Progress Towards Sustainable Development in Venice: A Comparative Assessment of Methods and Approaches". SSRN Electronic. Retrieved from https://papers.ssrn.com/sol3/papers.cfm?abstract_id=275133 on April 21, 2019.

Sudarwanto, B., Pandelaki, E. E., \& Soetomo, S. (2014). "Achievement of Sustainable Housing 'Selection of Indicators in the Preparation of a Sustainable Framework'[In Indonesian]". Modul, 14(2), 105-112.

Suryani, E. (2016). "Waste Bank Management in Bekasi City [In Indonesian]." Jurnal Administrasi Dan Kebijakan Publik UNISMA, 6(1), 63-75.

Talen, E. (2014). "Urban and Regional Sustainability". In Fisher and Nijkamp (Eds.), Handbook of Regional Science. New York \& London: Springer.

Turcu, C. (2013). "Re-Thinking Sustainability Indicators: Local Perspectives of Urban Sustainability". Journal of Environmental Planning and Management, 56(5), 695-719. doi: https://doi.org/10.1080/09640568.2012.698984.

United Nations. (2015). "Science, Technology and Innovation for Sustainable Urbanization."

WCED. (1987). Our Common Future, World Commission on Environmental and Development. Oxford: Oxford University Press.

Wheaton, B., Muthén, B., Alwin, D. F., \& Summers, G. F. (1977). “Assessing Reliability and Stability in Panel Models". Sociological Methodology, 8, 84-136. doi: https://doi.org/10.2307/270754.

Winston, N., \& Eastaway, M. P. (2008). "Sustainable Housing in the Urban Context: International Sustainable Development Indicator Sets and Housing". Social Indicators Research, 87(2), 211-221. doi: https://doi.org/10.1007/s11205-007-9165-8.

World Bank. (2009). "Reshaping Economic Geography".

World Bank. (2017). "Governance and The Law".

Xu, Y., Keivani, R., \& Cao, A. J. (2018). "Urban Sustainability Indicators Re-Visited: Lessons from Property-Led Urban Development in China". Impact Assessment and Project Appraisal, 36(4), 308-322. doi: https://doi.org/10.1080/14615517.2018.1447735.

Yandri, P. (2014). "Residential Area and Income Inequality in Suburban Indonesia". Indonesian Journal of Geography, 45(1), 69-77.

Yandri, P. (2015). "Residential Area in Suburban Indonesia Today: Conflicts and the New Pattern of Residential Segregation". Sustainable Megacities: Vulnerability, Diversity, and Livability. Presented Paper, The 5th International Conference of Jabodetabek Study Forum, IPB International Convention Center.

Yandri, P. (2017). "The Political Geography of Voters and Political Participation: Evidence from Local Election in Suburban Indonesia”. Indonesian Journal of Geography, 49(1), 5764.

Yigitcanlar, T., Kamruzzaman, M., \& Teriman, S. (2015). "Neighborhood Sustainability Assessment: Evaluating Residential Development Sustainability in a Developing Country Context". Sustainability, 7(3).

Zhao, P. (2016). "Planning for Social Inclusion: The Impact of Socioeconomic Inequities on the Informal Development of Farmland in Suburban Beijing”. Land Use Policy, 57, 431443. doi: https://doi.org/10.1016/j.landusepol.2016.06.010. 